\title{
The Influence Of Ethics Instructions On Ethical Judgment Of Minority Students
}

Augustus Abbey, Morgan State University, USA

Binta Abubakar, Morgan State University, USA

Fikru H. Boghossian, Morgan State University, USA

\begin{abstract}
Recent ethical scandals in corporate America have brought to the fore the issue of ethics in business. Many have questioned the role of the American educational system in general and the business school curriculum in particular for failing to inculcate in students and future business leaders good ethical standards. This exploratory study examines the influence of ethics instruction on the ethical judgment of students. Business students in an accredited (AACSB International) business program who have taken at least two formal courses in business ethics were compared to engineering seniors and freshmen business students who had not been introduced to formal instructions in ethics. Respondents were exposed to realistic ethical business scenarios dealing with conflict of interest transactions and personal integrity. The results showed a significant difference between the two groups of respondents on conflict of interest scenarios but no difference on personal integrity scenarios. Implications are considered for ethics education.
\end{abstract}

Keywords: Ethics, Business School, Judgment and Education

\section{INTRODUCTION}

$\mathscr{R}$

Tecent ethical scandals in the corporate America have brought to the fore the issue of ethics in America. Many have attributed the unethical conduct at Enron, WorldCom, Tyco, Adelphia, and Arthur Anderson to pure greed (Moskowitz, 2002; Kelly, 2002). The educational system in the United States of America in general and business education in particular, have been criticized for their failure to inculcate in students the standards of good conduct (Gardner, 1991; Kohlberg, 1984; Rest, 1984, 1988); and may even have weakened the moral character of students (Etzioni, 2002).

Despite the questions raised about the role of business schools in ethical conduct of former students, there is a strong prevailing view that exposure of individuals to good ethical practices will have positive influence on ethical behavior (Allen, 1992; Alder, 2002; de Russy, 2003; Davis, 2003; Farnsworth et al, 2003; Windsor, 2005). The Association to Advance Collegiate School of Business (AACSB International), the main accrediting agency for business schools and colleges, had long required the teaching of ethics in the business curricula and as a condition of accreditation. A task force formed in response to the corporate scandals of the 1990s argued for the need to strengthen business ethics education. The task force report designed to "urge and encourage administrators and faculty in business education to contemplate their current approaches to ethics education and to explore methods to strengthen this vital part of the curriculum." (AACSB - International, 2004). The task force identified four themes which should serve as the basis for ethics education in the curriculum: (1) the responsibility of business in society, (2) ethical decision-making, (3) ethical leadership, and (4) corporate governance (AACSB - International, 2004). Windsor (2005) argued in response to the crisis in business ethics that schools of business be required to offer a foundation course in business ethics as a condition for accrediting business programs.

The basic assumption of this school of thought is that exposure to courses in ethics would positively impact on ethical behavior and help students differentiate between proper and improper ethical behavior. However, not everyone agrees with this school of thought. Rohatynn (1988) argued that by the time individuals reach adolescence, their ethical personality and character have been formed and cannot be changed by education. Gardner (1991) also 
argued that scholastic knowledge seems strictly bound to school settings and when confronted with moral issues outside of the academic settings, students simply revert back to their earlier forms of moral reasoning.

\section{CONCEPTUAL BACKGROUND}

Numerous studies have empirically examined business ethics and ethical judgment among both students and professionals. Most of these studies have focused on factors such as the environment (Peterson, Rhoads and Vaught, 2001; Wimbush, Shepard and Markham, 1997)); education, age (Peterson et al, 2001; Ruegger and King, 1992); vocation and career stage (Weeks et al, 1999; Cole and Smith, 1995; David et al, 1994); and gender (Weeks et al, 1999; Cole and Smith, 1995; Whipple and Swords, 1992). Of these variables, perhaps, interest in gender as an antecedent variable has received the most attention (Weeks et al, 1999). Some studies on gender and ethics support the notion that females are generally more ethical than males (Glover et al, 2002; Weeks et al, 1999; Cole and Smith, 1995). Other studies found no such difference (Jones and Hiltebeital, 1995; David et al, 1994; Sikula et al, 1992; Davis and Welton, 1991). The findings, to say the least, have been inconsistent.

Review of the literature shows very limited attention has focused on the influence of ethics training or exposure of ethics courses on ethical judgments. Does exposure to ethics courses make a difference in the ethical judgment of people? Rest (1988) argued that courses in moral education do not facilitate moral development of students but rather interventions such as "dilemma discussion interventions and personality development interventions" facilitate moral development. Cole and Smith (1995) examined the effects of ethics instructions on the ethical perception of business students and concluded that exposure to ethics instruction did not significantly impact on the students' perception of what constitutes good ethical behavior. Roderick, Jelley, Cook and Forcht (1991) in a study involving upper division business students, found that about thirty percent of the respondents were willing to engage in an illegal activity for profit if the chances of being caught were minimal. This finding is consistent with the findings of other studies dealing with students' willingness to cheat in the classroom (Bunn, Candill and Gropper, 1992; Roberts and Rabinowitz, 1992; Aiken, 1991).

Despite these findings to the contrary, the popular assumption of ethics instruction is that exposure to ethics instruction would influence students' ethical judgment. AACSB International's push to "encourage administrators and faculty in business education to contemplate their current approaches to ethics education and to explore methods to strengthen this vital part of the curriculum" (AACSB, 2004). Boss (1994) contends that ethics courses provide students with resources that enable them to recognize situations requiring "moral judgment and action." Several other studies have advocated the inclusion of ethics courses in the business curriculum (Stead and Miller, 1988; Hatton, 1996; Lampe, 1997; Loo, 2001; Brady, 1999).

The question of whether exposure to classroom ethics instruction would have positive impact on ethical behavior is unsettled. This study will attempt to examine the popular assumption that exposure to ethics instruction will positively impact on individuals' ethical behavior. If this were the case, then it is to be expected that business students who have been exposed to ethics instructions in the business curriculum will demonstrate higher standard of ethical judgment than non-business students or even first and second year business students who are yet to be exposed to formal ethics instruction. Secondly, does gender play a role in ethical perception and judgment? Previous findings have been inconsistent about ethical differences between males and females.

The following hypotheses were established for the study:

H1: Respondents who have been exposed to ethics instructions will respond differently to ethical dilemmas than those who have not been exposed to formal ethics instruction.

H2: Male and female respondents who have similarly been exposed to formal instructions in ethics will respond in a similar fashion in situations involving ethical dilemmas.

In the higher education sector in the USA, Business schools have taught ethics at all level, yet several researchers have demonstrated that students enrolled in these schools exhibit lower ethical standards and a greater pragmatic orientation than practicing managers (Roderick, et al 1991, Arlow and Ulrich, 1980; Longenecker et al 
1989). In a study by Roderick, et al (1991) one third of the students surveyed said they would perform an illegal act for profit in the business world if the chances of them getting caught were slim. Longenecker et al (1989) posit that younger business personnel are significantly more permissive than older personnel in their views regarding ethics in a wide variety of decision situations.

\section{RESEARCH METHODOLOGY}

The study used the Lysonski and Gaidis (1991) method, so as to provide an opportunity to compare findings. Three groups of students attending a university in Maryland, Eastern part of the USA were selected for this study. One group consisted of freshmen business students who were enrolled in an introductory orientation course. The second group of respondents consisted of senior level engineering students. These two groups of students had not been exposed to any formal instructions in business ethics. The third group of respondents consisted of senior level business students who had taken the three ethics courses or ethics-related courses required for graduation, namely, Legal and Ethical Environment of Business, Business Law, and Business, Ethics and Society. A total of three hundred questionnaires were distributed out of which one hundred and sixty (160) questionnaires were returned. The questionnaires were distributed by the authors. Eleven (11) questionnaires were rejected because the responses were incomplete. Thus the usable response rate was about 50 percent. The respondents consisted of 38 percent male and 57 percent female, aged from 18 to 30, with 21 to 23 years old making 53 percent of the overall data collected. The data were subjected to statistical programs for the social sciences, multivariate analysis and oneway analysis of variance (ANOVA), to compare means and determine the difference between the three groups of students.

\section{MEASURES OF ETHICAL JUDGMENT}

The questionnaire consisted of vignettes or scenarios adapted from Lysonski and Gaidis (1991). Four vignettes are included in this paper for analysis. The original questionnaire consisted of ten vignettes which were designed to measure students' responses to ethical dilemmas in the following areas: (1) coercion and control (2) conflict of interest (3) physical environment (4) paternalism and (5) personal integrity. These vignettes were developed from ethical cases and problems. The study focused on ethical conduct involving conflict of interest and personal integrity situations. Two vignettes each were used to assess students' responses to ethical dilemmas dealing with conflict of interest and personal integrity were selected and used in this study. For purposes of this study, conflict of interest is said to exist when an individual in a position of trust acts in such a way where personal interest comes in conflict with official responsibilities. On the other hand, issues involving personal integrity arise when an individual's actions or decisions are contrary to his/her conscience.

The following two scenarios constituted conflict of interest vignettes:

1) You can use your company position to see that your company signs a 5-year contract which is 5 percent more than the current market price with your personal private business. What are the chances you would use your influence to win such a contract for your personal gain?

2) You are asked by your new employer to provide proprietary information about your previous employer. What are the chances that you would provide your employer with this information?

For personal integrity scenarios, the following two vignettes were used:

1) Test results show that an auto part that your firm designs does not meet specifications and causes accidents in extreme conditions. You must ship the part or else your firm would lose the contract. If you were involved in the situation, would you notify the auto manufacturer?

2) Your product is currently sold at $\$ 55$ in most retail stores. You are going to run a promotion campaign which will include dropping the price to $\$ 44.95$. You wonder if you should claim in the campaign that it was originally sold for $\$ 69.95$. This will make your discount appear to be bigger than it actually is. Should you include the higher list price in your promotions? 
Respondents were asked to indicate how they would respond to each scenario by indicating on a scale ranging from 0 (Definitely would take action) to 9 (Definitely would not). In addition, the respondents were asked to provide demographic data on classification, discipline, gender, and the exposure of ethics courses.

\section{RESULTS}

A multivariate analysis of variance was performed using undergraduate degree pursued and college classification (freshman, senior) as independent variables and the responses to the four ethical judgment vignettes as dependent variables.

\section{Conflict Of Interest:}

Vignette 1: You can use your company position to see that your company signs a 5-year contract 5 percent above current market price with your personal private business. What are the chances you would use your influence to win such a contract for personal gain.

Vignette 2: You are asked by your new employer to provide proprietary information about your previous employer. What are the chances that you would provide your new employer with this information?

Table 1 shows significant difference between respondents who have been exposed to formal instruction in ethics (business seniors) and respondents who have not been exposed to formal instruction in ethics (business freshmen and engineering seniors) on the two conflict of interest scenarios $(\mathrm{p}<.05)$.

Table 1

Comparison of responses to conflict of interest scenarios by discipline and classification

\begin{tabular}{|c|c|c|c|c|c|}
\hline Variables & $\begin{array}{c}\text { Business } \\
\text { Freshmen } \\
(\mathbf{n = 5 3 )}\end{array}$ & $\begin{array}{c}\text { Business } \\
\text { Senior } \\
(\mathbf{n = 6 5})\end{array}$ & $\begin{array}{c}\text { Engineering } \\
\text { Seniors } \\
(\mathbf{n = 3 2})\end{array}$ & F-Prob. & Sig. Level \\
\hline & Mean & Mean & Mean & & \\
\hline Conflict of Interest: & & & & & \\
\hline Vignette 1 & 4.86 & 5.80 & 5.72 & 5.832 & $0.017^{*}$ \\
\hline Vignette 2 & 6.09 & 6.48 & 5.34 & 6.345 & $0.13^{*}$ \\
\hline
\end{tabular}

$\mathrm{p}<0.1 ; *=\mathrm{p}<0.05, * *=\mathrm{p}<0.01, * * *=\mathrm{p}<0.001$

\section{Personal Integrity:}

Vignette 3: Test results show that an auto part that your firm designs does not meet specifications and causes accidents in extreme conditions. You must ship the parts or your firm will lose the contract. If you were involved in the situation, would you notify the auto manufacturer?

Vignette 4: Your product is currently sold at $\$ 55$ in most retail stores. You are going to run a promotion campaign which will include dropping the price to $\$ 49.95$. You wonder if you should claim in the campaign that it was originally sold for $\$ 69.95$. This will make your discount appear to be bigger than it actually is. Should you include the higher list price in your promotions?

Table 2 shows lack of significant difference between respondents who have been exposed to ethics instructions (business seniors) and respondent who have not been exposed to formal instructions in ethics (business freshmen and engineering seniors on the two personal integrity scenarios $(\mathrm{p}=\mathrm{ns})$ 
Table 2

Comparison of responses to personal integrity scenarios by discipline and classification

\begin{tabular}{|c|c|c|c|c|c|}
\hline Variables & $\begin{array}{c}\text { Business } \\
\text { Freshmen } \\
(\mathbf{n = 5 3 )}\end{array}$ & $\begin{array}{c}\text { Business } \\
\text { Senior } \\
(\mathbf{n = 6 5})\end{array}$ & $\begin{array}{c}\text { Engineering } \\
\text { Seniors } \\
(\mathbf{n = 3 2})\end{array}$ & F-Prob & Sig. Level \\
\hline & Mean & Mean & & & \\
\hline Personal Integrity & & & 4.72 & 0.769 & $0.382 \mathrm{~ns}$ \\
\hline Vignette 3 & 4.09 & 4.34 & 5.69 & 5.205 & $0.108 \mathrm{~ns}$ \\
\hline Vignette 4 & 5.45 & 6.28 & & \\
\hline
\end{tabular}

ns=non-significant

Gender differences were explored in this study to determine if there were significant differences between the males and females on all four vignettes. The analysis focused on male and female business seniors who have all been exposed to formal ethics instructions. Table 3 shows no significant difference between the males and females on both the conflict of interest judgment and judgments involving personal integrity.

Table 3

Comparison of ethical judgments by classification and gender

\begin{tabular}{|c|c|c|c|c|}
\hline & \multicolumn{2}{|c|}{ Business Seniors } & \multirow[b]{2}{*}{ F.Prob. } & \multirow[b]{2}{*}{ Sig. Level } \\
\hline & $\begin{array}{l}\text { Males } \\
(n=24)\end{array}$ & $\begin{array}{c}\text { Females } \\
(n=41)\end{array}$ & & \\
\hline \multicolumn{5}{|c|}{ Conflict of Interest } \\
\hline Vignette 1 & 5.25 & 5.44 & 0.26 & $0.87 \mathrm{~ns}$ \\
\hline Vignette 2 & 6.17 & 6.66 & 0.46 & $0.50 \mathrm{~ns}$ \\
\hline \multicolumn{5}{|c|}{ Personal Integrity } \\
\hline Vignette 3 & 4.42 & 4.29 & 0.22 & $0.88 \mathrm{~ns}$ \\
\hline Vignette 4 & 5.42 & 5.90 & 0.86 & $0.36 \mathrm{~ns}$ \\
\hline
\end{tabular}

ns $=$ non-significant

\section{DISCUSSION}

The relationship between formal ethics instruction and ethical judgment was explored by comparing respondents (business seniors) who had taken three formal ethics courses as required by the business curriculum and respondents (business freshmen and engineering students) who had not been exposed to any formal courses in ethics. Respondents, all university students were asked to respond to scenarios requiring ethical judgment on issues involving conflict of interest and personal integrity.

Hypothesis 1 was partially supported by the findings of the study. The findings suggest that there is a significant difference between respondents who had taken formal classes in ethics and those who had not when it came to ethical judgment about conflict of interest. On the question of personal integrity, the findings did not show any difference between the two groups. In other words, ethics instruction plays a significant role in conflict of interest situations. It appears that the knowledge gained from exposure to ethics instruction creates an awareness (Boss, 1994) that allows the respondent to identify conflict of interest situations that may not be obvious to the untrained person. The findings on the conflict of interest scenario support the contention of those who have argued that ethics should be taught in business schools (Boss, 1994; Stead and Miller, 1988; Brady, 1999; Loo, 2001; Farnsworth and Kleiner, 2003). Based on the finding here, ethics must be taught not only in business schools but across the curriculum and across campus.

Ethics instruction did not make a difference in the ethical judgment of respondents on issues involving personal integrity. The finding here failed to support hypothesis 1 . The lack of significant difference here, however, supports the contentions of Rohatynn (1988) that the ethical personality and character of the individual is formed 
before adolescence and cannot be changed by education. Others have expressed similar views about the limited influence of ethics instruction on ethical behavior (Gardner, 1991, Wolfe, 1993; Cole and Smith (Weeks et al, 1995).

Hypothesis 2 was not supported by the findings of this study. A majority of studies on gender differences have concluded that females are in general more ethical that males (Glover et al, 2002; Weeks el al., 1999; White Jr., 1999; Cole and Smith, 1995; Harris, 1989). Gender differences have been attributed to factors such as different ethical value-based decision making process (Harris, 1989) and differences in moral development (White, Jr., 1999). This study did not find any difference between male and female respondents. Both groups of respondents had taken formal ethics courses as required by their curriculum. This finding is consistent with the findings of Sikula and Costa (1994) who found no significant differences between the ethical values of male and female students but found differences on other non-ethical values. It may well be that females are more ethical than males but it appears in this study that ethics instructions may mitigate the significance of the difference between the male and female respondents. Given the small sample size used in this analysis, it is recommended that future research focuses on this issue.

\section{CONCLUSION AND IMPLICATIONS}

The findings of this study have implications for corporate America. The introduction of ethics instruction by way of organized workshops and other programs will be worthwhile because the acquisition of knowledge about ethics will enable employees to be aware of ethical pitfalls in conflict of interest situations. It can be inferred from the findings of this study that ethics instruction is not a panacea for all unethical behavior. Formal exposure to ethics instruction will not make a difference in ethical issues dealing with moral consciousness and ethical character of individuals which are "formed before the age of adolescence" (Rohatynn, 1988). The enduring nature of ethical personality and character is supported by Gardner (1991) who established in a study that when students were confronted with moral issues outside the academic setting, they revert back to their earlier forms of moral reasoning. Rest $(1986,1993)$ argued that age, education and life experiences are primary determinants of moral development. Future research is necessary to better understand the role of ethics instructions on ethical judgment and the likely relationship between ethics instruction and moral development. This will help develop a better paradigm for influencing good ethical behavior.

\section{REFERENCES}

1. Albrecht, G. and Weber, L. J. (1994), "Personal Commitments, Privileged positions and the teaching of Applied Ethics," Professional Ethics, 3(3) \& (4), 141-155

2. Association to Advance Collegiate Schools of Business International (2004). Ethics Education in Business Schools. Report of the Ethics. Educational Task Force to AACSB International Board of Directors, June 2004.

3. Boss, Judith (1994) "The Effect of Community Service Work on the Moral Development of College Ethics Students." Journal of Moral Education, 23(2), 183

4. Brady, F.N. (1999) “A Systematic Approach to Teaching Ethics in Business," Journal of Business Ethics, 19, 309-318.

5. Bunn, D. N., Caudill, S. B., and Gropper, D.M. (1993) "Crime in the Classroom: An Economic Analysis of Undergraduate Student Cheating Behavior, Journal of Economic Education, 23, 197-207.

6. Cole, B. C., and Smith, D.L (1995), "Effects of Ethics Instruction on the Ethical Perceptions of College Business Students," Journal of Education for Business, 70(6), 351-356.

7. David, J. M., Kantor, J., and Greenberg, I (1994) "Possible Ethical Issues and their Impact on the Firm: Perceptions held by Public Accountants," Journal of Business Ethics, 13, 919-937.

8. Davis, J. R. and Welton, R. E. (1991) “Professional Ethics: Business Students' Perceptions,” Journal of Business Ethics, 10, 451-463.

9. De Russy (2003) "Professional Ethics begins on the College Campus," Chronicle of Higher Education, 50(4), B20.

10. Etzioni, A. (2002) "Profit Without Honor: When It Comes to Ethics, B-Schools Get an F," The Washington Post, Sunday, August 4, pp. B4. 
11. Farnsworth, J., and Kleiner, B. H. (2003) "Trends in Ethics Education at US Colleges and Universities," Management Research News, 26, 2.

12. Gardner, H. (1991) "The Tension between Education and Development," Journal of Moral Education, 20(2), 113-125.

13. Glover, S. H., Bumpus, M., Sharp, G. and Munchus, G. (2002) "Gender Differences in Ethical Decision Making," Women in Management Review, 17(5), 217-227.

14. Harris, J. R., (1989) "Ethical Values and Decision Processes of Male and Female Business Students," Journal of Education for Business, 8, 234-238.

15. Hatton, L (1996) "Integrating ethical awareness into the curriculum," Journal for Education in Business, 71(4), 237-240.

16. Jones, S. K. and Hiltebeitel, K. M., (1995) "Organizational Influence in a Model of the Moral Decision Process of Accountants," Journal of Business Ethics, 14, 417-431.

17. King, V., Elder, G.H., and Whitbeck, L.B. (1997) "Religious Involvement among Rural Youth: An Ecological and Life-Course Perspective," Journal of Research on Adolescence, 7(4), 431-456.

18. Lampe, M. (1997), "Increasing effectiveness in teaching ethics to undergraduate business students," Teaching Business Ethics, 1(1), 3-19.

19. Loo, R. (2001), Encouraging classroom discussion of ethical dilemmas in research management: three vignettes," Teaching Business Ethics, 5, 195-212.

20. Lysonski, S. and Gaidis, W., (1991). "A Cross-cultural comparison of the ethics of business students," Journal of Business Ethics, 10, 141-150.

21. McCarthy, M. A., and Horn, E. (1996). "An examination of moral development in specific subpopulations. Paper presented at the annual meeting of the American Educational Association, New York, NY, April 812, 1996.

22. Miesing, P. and Preble, J. F. (1985). “A comparison of five business philosophies.” Journal of Business Ethics, 4, 465-476.

23. Neff, J. A. and Husaini, B.A. (1987) "Urbanicity, race and psychological distress," Journal of Community Psychology, 15, 520-536.

24. Nelson, D.R. and Obremski, T.E. (1990), "Promoting moral growth through intra-group participation," Journal of Business Ethics, 9, 731-739.

25. Paykel, E. S., Abbott, R., Jenkins, R. et al (2000) "Urban-Rural Mental Health Differences in Great Britain: Findings from the National Mobility Survey," Psychological Medicine, 30, 269-280.

26. Peterson, D., Rhoads, A., and Vaught, B. (2001) "Ethical Beliefs of Business Professionals: A Study of Gender, Age and External Factors," Journal of Business Ethics, 31, 225-232.

27. Rest, J. R. (1984) “The Research on Moral Development: Implication for Training Counseling Psychologists," The Counseling Psychologist, 12(2), 19-29.

28. (1988). "Why does college promote development in moral development? Journal of Moral Education, 17(3), 183-194.

29. Roberts, D., and Rabinowitz, W. (1992) “An Investigation of Student Perceptions of Cheating in Academic Situations. Review of Higher Education, 15(2), 179-190.

30. Roderick, J. C., Jelley, H. M., Cook, J. R. and Forcht, K. A. (1991) "the Issue of White Collar Crime for Collegiate Schools of Business," Journal of Education for Business, 66, 287-290.

31. Ruegger, D., and King, E. W. (1992) "A Study of the Effect of Age and Gender upon Student Business Ethics," Journal of Business Ethics, 11, 179-186.

32. Sikula, A., and Costa, A. D (1992) "Are Woman More Ethical than Men? Journal of Business Ethics, 13, 859-871.

33. Stead, B. A. and Miller, J. J. (1988) "Can Social Awareness be Increased through Business School Curricular?" Journal of Business Ethics, 7, 553-560.

34. Sandquist, K., Frank, G., and Sandquist, J. (2004) "Urbanization and Incidence of Psychosis and Depression," British Journal of Psychiatry, 184, 293-298.

35. Whipple, T.W., and Swords, D. F. (1992) "Business Ethics Judgment: A Cross-Cultural Comparison," Journal of Business Ethics, 11, 671-678.

36. White, Jr., R. D. (1999) “Are women More Ethical? Recent Findings on the Effects of Gender Upon Moral Development, "Journal of Public Administration Research and Theory, 3, 459-471. 
37. Wimbush, J. C., Shepard, J. M., Markham, Steven, E., (1997). "An Empirical Examination of the Relationship between Ethical Climate and Ethical Behavior from Multiple Levels of Analysis," Journal of Business Ethics, 16, 1705-1716.

\section{NOTES}

